\title{
CORPORATE SOCIAL RESPONSIBILITY STRATEGIES OF SPANISH LISTED FIRMS AND CONTROLLING SHAREHOLDERS' REPRESENTATIVES
}

\begin{abstract}
This paper aims at analyzing how controlling shareholders' representatives on boards impact on corporate social responsibility (CSR) strategies (disclosing CSR matters) in Spain, a context characterized by high ownership concentration, one-tier boards, little board independence, weak legal protection for investors and the presence of large shareholders, especially institutional shareholders. Furthermore, among controlling shareholders' representatives, we can distinguish between those appointed by insurance companies and banks and those appointed by mutual funds, investment funds and pension funds. The effect of these categories of directors on CSR strategies is, therefore, also analyzed. Our findings suggest that controlling shareholders' representatives have a positive effect on CSR strategies, as do directors appointed by investment funds, pension funds and mutual funds, while directors appointed by banks and insurance companies have no impact on CSR strategies. This analysis offers new insights into the role played by certain types of directors on CSR strategies.
\end{abstract}

Key words: Corporate social responsibility strategies, controlling shareholders' representatives, directors appointed by insurance companies and banks, directors appointed by pension funds, mutual funds and investment funds, agency theory, stakeholder theory. 


\section{CORPORATE SOCIAL RESPONSIBILITY STRATEGIES OF SPANISH LISTED FIRMS AND CONTROLLING SHAREHOLDERS' REPRESENTATIVES}

\section{INTRODUCTION}

Corporate social responsibility (CSR) can be defined as "a concept whereby companies integrate social and environmental concerns in their business operations and in their interaction with their stakeholders on a voluntary basis" (European Commission, 2001:7). This description underlines the idea that firms voluntarily become involved with society and the environment in order to enhance and improve them. As noted by Santos (2011), this definition of CSR combines diverse objectives that must be integrated into the management process and go hand in hand with the objective of achieving positive economic outcomes.

The rapid globalization process has placed companies on a new stage where they are more aware of promoting CSR disclosure. In other words, if firms want to survive in today's very competitive environment, they will have to adapt to the global economy and, as a consequence, they will not only have to pay attention to the economic dimension, but will also have to increase their interest in the social and environmental dimensions of their businesses. Additionally, the pressure exerted by a company's interest groups, including nongovernmental organizations (NGOs), customers and their own workers, as well as stricter laws on CSR matters, have meant that firms must be held accountable for their economic, social and environmental activities if they wish to be competitive. Thus, globalization has raised the priority of CSR disclosure on the agenda of Spanish listed firms, since they have to behave in a similar way to other listed firms around the world in order to compete in international markets that have become more socially aware, and the true driver of disclosing CSR matters among Spanish listed companies has been increased social awareness (Olcese, 2012). 
Authors such as Morsing and Schultz (2006) support the view that firms must be responsible to all of their stakeholders, because their activities have consequences not only for those belonging to the firm, but also for third parties. Waddock (2003) argues that firms are interested in adopting CSR as a business management model because they can develop systems and policies based on benefits to the company and its stakeholders. Therefore, although the first reason for integrating CSR is to be sustainable over the long term, companies must also consider broader social and environmental dimensions. The importance of firms' social practices has generated a demand for information to allow judgments to be made as to the extent to which companies are ethical and, consequently, public reports on CSR are essential to identify which companies are, or are not, committed to society and all their stakeholders.

Thus, these views highlight the importance of firms' CSR disclosure for society, practitioners and academia. First, in the current context, CSR reporting is relevant for society since the purpose of CSR programs is to satisfy social requirements (Angelidis and Ibrahim, 1993). Society is interested in knowing what firms are doing in relation to CSR matters. Some of these matters may affect society and, therefore, society pushes firms to show their commitment to CSR issues in order to satisfy the demands of stakeholders (among which society is included). Firms may report CSR information with the purpose of demonstrating their commitment. In this sense, CSR reporting becomes an important mechanism by which society assesses these purposes. Second, practitioners, particularly those familiar with CSR matters, are conscious that firms not involved with CSR issues may have a reputational crisis and, as a result, have to find out which values are most important for their stakeholders in order to satisfy their demands. In line with this, CSR reporting is gaining in importance as it allows practitioners to keep stakeholders informed about firms' CSR matters, thus avoiding a reputational crisis and helping them to improve the relationship between firms and society. 
Practitioners are interested in providing understandable CSR reports and achieving a good reputation because this is likely to have positive repercussions on a firm's profits. Finally, CSR literature has received growing attention in recent decades since there is a gap to be filled regarding how CSR disclosure impacts different business decisions. Thus, CSR reporting helps researchers to collect data in order to show evidence of these issues and, accordingly, this evidence may also be useful for supervisory bodies, practitioners and society.

Sánchez-Ballesta and García-Meca (2007) show that corporate governance mechanisms generate corporate behavior that influences CSR disclosure. Cuadrado-Ballestero et al. (2015) place specific emphasis on the influence of boards on CSR disclosure, with particular reference to size and independence, for example. Systematic reviews by Hahn and Kuhnen (2013) and Dienes et al. (2016) also identify board independence and size as corporate governance structure determinants affecting CSR disclosure (e.g., Jizi et al., 2014). Other identified determinants are board activity measured as board meetings (e.g., Kent and Monem, 2008), board gender diversity (e.g., Fernandez-Feijoo et al., 2014) and CEO duality (e.g., Jizi et al., 2014). An excellent revision of past and recent research focused on the influence of these corporate governance determinants on CSR reporting can be found in Hahn and Kuhnen (2013) and Dienes et al. (2016). Miras-Rodríguez et al. (2015) also underline that cultural, legal and political aspects may affect a firm when it makes decisions on CSR. However, little attention has been paid to other board characteristics, such as the presence of institutional directors.

This analysis has shown that institutional directors, who represent institutional investors such as pension funds, insurance companies and banks, have increased their influence on the financial markets as they have abandoned their former passive roles on company boards and, consequently, have begun to perform an important role in monitoring 
management teams (López-Iturriaga et al., 2015). In this regard, previous research demonstrates that these directors have an effect on leverage (e.g., David et al., 2001) and financial reporting quality (e.g., Pucheta-Martínez and García-Meca, 2014), inter alia. Institutional activism (direct involvement) may lead to firms being more involved in socially responsible investments and practices. In this sense, institutional investors have increased their activism concerning CSR in an attempt to integrate social, ethical and environmental matters in their businesses. Institutional investors may participate as directors and shareholders in the decision-making process of a firm and, thereby, can play a relevant and active monitoring role in relation to managers, since they are concerned about their reputation and, consequently, will put pressure on firms to disclose CSR information. Hence, institutional investors will endorse the sustainability of companies in which they have invested.

Accordingly, the impact of institutional directors on the governance of firms, the positive effects that CSR can have on companies, the daily attention given by boards to CSR matters and the small amount of research that has explored the association between corporate governance mechanisms and CSR (e.g., Fernández-Sánchez et al., 2011) provide us with the motivation to examine the impact of institutional directors on strategic company decisions like CSR disclosure. Therefore, the purpose of this research is to analyze how CSR disclosure by Spanish listed companies is affected by the presence of institutional directors on their boards. In addition, past literature (e.g., Almazán et al., 2005; Choi et al., 2012) has shown that it is important not to consider institutional directors as a homogeneous group. In this sense, López-Iturriaga et al. (2015), among others, emphasize that "the type of business relation between firms and institutional investors is the key to describing the role of institutional directors". In this sense, we distinguish between pressure-sensitive institutional directors, who represent pressure-sensitive investors who maintain both an investment and a 
business relationship with the firm, and pressure-resistant institutional directors, who represent pressure-resistant investors who only maintain an investment relationship with the firm. Past and recent research has also distinguished between pressure-sensitive and pressureresistant institutional directors (e.g., Almazán et al., 2005; Choi et al., 2012; López-Iturriaga et al., 2015), arguing that pressure-sensitive directors are more likely to be influenced by managers. The fact that pressure-sensitive investors maintain commercial ties with the firm explains the term "pressure-sensitive" because these investors are under pressure from the management team since they do not want to lose their business links; consequently, they are more sensitive to pressure. This view is supported by Davis and Thompson (1994), who argue that proxy voting allows managers to know whether institutional investors voted against them or with them. Consequently, various institutional investors (banks and insurance companies) are pressed to support managers' agendas due to their actual or potential business operations with firms, which involve dealing with managers. In contrast to this, pressure-resistant investors do not maintain such commercial relationships and, as a result, are not under such pressure and can behave more independently (Davis and Thompson, 1994), which explains the expression "pressure-resistant". Hence, we also explore the effects of pressure-sensitive and pressure-resistant directors on CSR reporting, since it is expected that they differ. This investigation is performed in Spain, which gives a different setting from other countries because, among other reasons, there is an important presence of controlling shareholders in firms, mainly institutional investors. An analysis of the role performed by institutional directors on CSR reporting, in an environment where institutions are important controlling shareholders, merits attention.

It is important to remark, in line with Font et al. (2012) and Bowen and Aragon-Correa (2014), that CSR disclosure and CSR commitment do not have to go hand in hand. In this sense, the fact that firms disclose CSR information about their environmental and social 
programs does not mean that they have to be responsible or commit to CSR, since it may be likely that they are only hoping to improve their reputation.

This paper contributes to the literature in several respects. First, our evidence reinforces the view that institutional directors protect the interests not only of the shareholders, but also of all stakeholders of the firm. Our findings show that institutional directors on boards encourage CSR disclosure; it is not only the shareholders who can benefit from this, but also all the other stakeholders, since CSR information is public and is accessible to both shareholders and stakeholders. Second, we fill the gap in the prior research concerning the role played by institutional directors in firms' CSR disclosure, since we show that institutional directors cannot be considered a uniform group: pressure-resistant and pressure-sensitive institutional directors behave differently with respect to CSR reporting. Third, we support the thesis that directors who are oriented towards the long term, such as pressure-resistant directors, are more likely to promote CSR disclosure, given the active monitoring role they play and because they are concerned about their reputation. Finally, our analysis provides an index that measures the level of CSR disclosure of a company, and this may be useful for NGOs, CSR observers, practitioners and researchers in determining which firms are more proactive in disclosing information on CSR.

The paper proceeds as follows: in section 2, we focus on the institutional setting; section 3 describes the theoretical background and develops the hypotheses; section 4 describes the sample, methodology and variables used in the study; section 5 provides the analysis of the findings; and the final section discusses the findings and conclusions, the limitations inherent to this study and future lines of research.

\section{INSTITUTIONAL SETTING}

In the last few decades, Spain has increased its interest in CSR policies because society is pressing companies to engage in sustainable production. For this reason, a growing 
number of CSR reports, guidelines, observers, studies, indicators and indexes have exerted an influence in changing Spanish business culture.

The Spanish Conthe Code (CUBG), issued in 2006, is a key aspect of this change. The Conthe Code (CUBG, 2006) provides three specific recommendations concerning CSR. The first makes reference to the inclusion of CSR disclosure in the corporate governance rules and internal codes of conduct, and states that this is supervised by a committee. The second refers to the minimum subject matter to be included in the CSR disclosure. In particular, the CSR disclosure should include details of specific practices on issues related to shareholders, employees, customers, suppliers, social and environmental matters, diversity, fiscal responsibility, respect for human rights and prevention of illegal behavior, and monitoring mechanisms for financial risk, ethics and business conduct. The third states that CSR issues should be reported in the management report, or in a separate report, using any of the different internationally accepted methodologies.

The most relevant features of Spanish corporate governance are the low level of board independence, the lack of active market control (the supervision of the capital markets by the government and financial authorities is weak because the most important source of finance for companies is the banking sector, and not the capital markets), the presence of dominant shareholders on boards, a high ownership concentration and family ownership, a one-tier board system (all the directors, both executive and non-executive, sit on the board) and a low level of legal protection for investors. In this context, dominant shareholders take important positions on the boards of Spanish listed firms, and exert a strong influence on the management because of the high ownership concentration and the weakness of investors' protection. Institutional investors are among the most important controlling shareholders in Spain and, consequently, they have an important influence on corporate governance (e.g., Crespí et al., 2004). Indeed, the boards of Spanish listed firms are characterized by the fact 
that $40 \%$ of directors are institutional directors appointed by institutional investors; this is the highest percentage among European countries (Heidrick and Struggles, 2011).

Thus, Spain offers a good setting in which to examine the role played by institutional directors, given their relevant presence on boards and given the little empirical evidence about the influence of institutional investors on CSR disclosure when they act as board directors, perhaps because the presence of institutional directors on boards appointed by institutional investors in the US and UK is less common.

\section{THEORETICAL BACKGROUND AND HYPOTHESES}

Stakeholder theory posits that a company should consider all the stakeholders that may affect or be affected by its activities (Freeman, 2010). This theory supports a link between business ethics and organizational management, as a result of which firms have to take into account not only their shareholders, but also a wider range of stakeholders, such as customers, the local community, and their employees, among others. Therefore, firms have to pay attention not only to their economic responsibilities, but also to the stakeholders' interests.

Most sustainable management research is based on the stakeholder perspective (e.g., Montiel and Delgado-Ceballos, 2014). To the extent that boards are responsible for setting the values and standards within their organizations, companies interested in integrating CSR policies and addressing the interests of different stakeholders may have to adapt their board composition and functioning to this new role. Authors such as Arjoon (2005) support the notion that directors have to demonstrate greater ethical responsibility and a stronger ethical attitude when conducting business than when they are not directors, because they represent not only the shareholders, but also the other stakeholders of the firm, and because society is putting pressure on them following the numerous scandals that came to light in the wake of the economic crisis. Walls et al. (2012) also stress the role of boards in relation to environmental performance, measured in two ways - as the addition of the values of the items 
of strength or as the addition of the values of the items of concern. In particular, they report that environmental performance is better if the board is more diverse, less independent and smaller. Thus, boards meeting these conditions are effective monitoring tools for environmental performance. In the same vein, Walls and Hoffman (2013) highlight the importance of the board of directors in supervising managers and affecting the firm's strategic orientation. These authors show that boards with greater environmental experience are more likely to diverge in a positive direction from institutional norms. Jain and Jamali (2016) argue that the board of directors is a "rich source of knowledge and guidance" and can, therefore, challenge managers to implement certain actions promoting the firm's CSR.

Galbreath (2016) posits that directors on boards are supposed to move towards the promotion of actions associated with CSR. Concretely, Galbreath (2016) proposes that board composition is a very important issue when a firm's CSR is explored, since board members are a heterogeneous group because of their differing incentives and temporal orientations. The author finds that insider directors show a short-term orientation that is contrary to the longterm orientation needed for CSR and, thus, that insiders have a negative impact on CSR reporting.

In continental European countries, particularly Spain, where listed firms are characterized by high ownership concentration, two types of directors are distinguished in their boards of directors: insiders (executive) and outsiders or non-executive. Executive directors are vested with wide managerial powers and guide the firm's management team, while non-executive directors are mainly tasked with monitoring functions. The boards tend to be numerous, mainly in big companies, and among non-executive directors, two kinds of directors can be considered: those representing the owners or controlling shareholders (institutional directors) and independent directors (a more detailed discussion of this matter can be found in Ferrarini and Felippelli, 2013). Whereas executive directors are insiders and 
are directly involved in the management of the firm, both independent and institutional directors are considered outsiders, with different agendas and incentives in terms of controlling managers. In this sense, independent directors are members who are "free of any business, family or other relationship with the company, its controlling shareholder or the management of either, that creates a conflict of interest such as to impair its judgment" (EU, 2005). Furthermore, independent directors are board members appointed in view of their recognized professional expertise, experience and prestige and are neither executive nor institutional directors, while institutional directors are those members who represent dominant institutional investors in the company that are involved somehow with the company and can influence the management of the firm.

Institutional directors have received attention from previous empirical research (e.g., Bhojraj and Sengupta, 2003; López-Iturriaga et al., 2015). Authors such as Hartzell and Starks (2003) suggest that institutional investors perform a relevant monitoring role and Parrino et al. (2003) emphasize their capacity to discipline managers and their active behavior in response to the corporate governance problems of firms. These characteristics involve an activism that is known as institutional shareholder activism. In this regard, Eesley et al. (2016) show that the activism of investors, such as institutional investors, is an important matter to take into account when examining social changes in companies, since these investors may press firms to report CSR information. Thus, it is logical to assume that firms with institutional directors on their boards are more likely to be transparent and, hence, to encourage CSR reporting, as the costs associated with the monitoring role of institutional directors will be lower in companies that disclose CSR issues. Furthermore, institutional directors tend to be more aware of social and environmental demands, taking responsibility in these areas (Harjoto and Jo, 2011). In other words, these directors take an active role and, thus, may influence CSR reporting as they are interested in their reputation. 
Furthermore, continental European base research, especially that conducted in Spain (e.g., García-Meca and Sánchez-Ballesta, 2009; Pucheta-Martínez and García-Meca, 2014), shows that independent directors on boards, in contrast to the US and UK, appear to be less effective in carrying out the theoretical role of monitoring and, therefore, the supervising role on boards is not played by independent directors, but by directors who represent controlling shareholders such as institutional investors.

Agency theory argues that institutional directors have incentives to act independently of managers and, therefore, will protect the interests of all the stakeholders, particularly shareholders, to mitigate agency costs (Colpan and Yoshikawa, 2012). Institutional directors should react to the expectations of the stakeholders, and institutional directors would therefore be expected to be more committed to CSR reporting demands, given that it might reinforce the internal control of companies and might decrease opportunistic behaviors due to asymmetric information, as Frías-Aceituno et al. (2013) suggest. Furthermore, CSR disclosure is a long-term responsibility of a firm and, accordingly, companies with institutional directors, who are usually associated with a long-term orientation, will have an interest in the long-term sustainability of the company and will be more likely to disclose CSR issues because they are necessary for long-term value creation and sustainable firm performance (Mahapatra, 1984). In this vein, the prior literature (e.g., Zattoni, 2011) shows that institutional directors exert a positive impact on CSR disclosure.

Likewise, from a legitimacy perspective, firms need to be legitimated by society (Patten and Crampton, 2004) in order to successfully run the business. If society notices that firms behave in an inappropriate manner, such legitimacy can be threatened, so in order to guarantee it, firms carry out legitimation strategies such as CSR reporting. In this regards, CSR disclosure becomes a mechanism for acquiring legitimacy and for protecting a firm's identity and reputation (Panwar et al., 2014). As a result, given that institutional directors are 
concerned with their reputation, they will be more likely to disclose CSR information. Additionally, CSR disclosure is viewed by institutional directors as crucial to attain competitive advantage and sustainability, as it can help companies achieve legitimacy through support from different stakeholders (Neubaum and Zahra, 2006).

In line with agency and legitimacy approaches, the signaling perspective posits that in situations of asymmetric information, firms signal efforts to disclose sustainability matters in order to reduce this asymmetry and to assure legitimacy in society (Connelly et al., 2010). CSR and sustainability issues may be viewed as such asymmetric information because not all stakeholders have access to this type of information. Hence, institutional directors will support decisions such as CSR disclosure in order to send signals to stakeholders. In this way, institutional directors may send a signal to third parties communicating companies' unobservable features, such as their commitment to environmental and social matters, thus preserving their reputation. Additionally, if stakeholders value these unobservable characteristics, they might reward firms (Ramchander et al., 2012).

Based on the above arguments, we posit the following hypothesis:

$\mathrm{H}_{1}$ : CSR disclosure is positively affected by institutional directors.

As stressed above, institutional directors (those who represent institutional investors on boards) are considered to be a heterogeneous group since their interests and incentives are dissimilar. In line with this, earlier research (e.g., Ramalingegowda and Yu, 2012) shows that institutional directors do not behave in a monolithic way, as they represent institutional investors who may or may not maintain business ties with the firm in which they invest and, thus, they may have different attitudes with regard to anti-takeover amendments, CEO compensation and CSR disclosure, inter alia. Such directors can be separated into two groups: pressure-sensitive institutional directors (those representing banks and insurance firms, who both invest in the firm and maintain commercial ties with it) and pressure-resistant 
institutional directors (those representing mutual funds, investment funds, pension funds and venture capital firms, who only invest in the firm). Huse (2007) also argues that the impact of institutional directors on boards depends on the type of ownership that they represent in companies. In this sense, while pressure-resistant institutional investors are oriented towards the long term, pressure-sensitive institutional investors are oriented towards the short term. The long-term orientation of pressure-resistant directors may explain why they are concerned about their reputation and, consequently, why they are more likely to reduce agency problems and to encourage social issues such as CSR disclosure. On the other hand, maximizing corporate performance and the expansion of their own businesses in order to achieve greater benefit are the results of the short-term orientation of pressure-sensitive directors. Their commercial ties with the firm may cause them conflicts of interest and, therefore, they will be less likely to encourage changes or to mitigate agency costs. Hence, the temporal horizon will determine the behavior of both types of institutional directors in their supervision of the management team in relation to reducing agency problems and disclosing CSR information. This idea is supported by Jain and Jamali (2016), who argue that pressure-sensitive investors such as banks have a short-term investment perspective and will be less interested in supporting CSR activities because these practices show their benefits in a long-term horizon; thus, pressure-sensitive investors consider the costs of CSR activities unnecessary. Meanwhile, pension funds (pressure-resistant investors) will be more likely to support CSR firms' disclosure because they have a long-term investment approach (more detail about this point can be found in Jain and Jamali's 2016 paper).

Pressure-sensitive institutional investors, as underlined above, tend to maintain both business and investment links with companies and, in order to preserve their business ties, may not be disposed to take issue with management decisions. Thus, because their profitability depends on it, pressure-sensitive institutional investors will tend to maintain a 
solid and excellent relationship with the firm. This view is supported by Almazán et al. (2005), who show that pressure-resistant directors can provide more intense managerial monitoring than pressure-sensitive investors because they are more active. According to Huse (2007), when pressure-sensitive institutional directors dominate the board, it will tend to align with managers rather than to control them.

The prior literature (e.g., Almazán et al., 2005; David et al., 1998) emphasizes the hypothesis that banks and insurance companies seek their own profit because of the design of their incentive systems. In this vein, Johnson and Greening (1999) find that pressure-sensitive institutional directors will try to put pressure on the company to adopt a short-term orientation, given their short-term profitability perspective. Hence, these authors suggest that such directors face more conflicts of interest in their relationship with the firm; thus, they will be less concerned about monitoring managers or CSR matters, for example. This idea is consistent with those of Eng (1999), who reports that insurance companies have a short-term horizon and, consequently, may not be interested in safeguarding the interests of stakeholders.

Within the category of pressure-sensitive institutional investors, banks are the most common, and pressure-sensitive institutional investors may, thus, become both shareholders and creditors. They may perceive that this dual role gives them access to more information than other types of shareholder, and they may use this information for their own interests. This may encourage the formation of controlling coalitions between such types of institutional investor and managers or other stakeholders, creating corporate groups to extract private benefits (Ali et al., 2007). Pressure-sensitive institutional directors will be less effective in monitoring managers, since they can be expected to align themselves with managers as they do not want to lose their business or potential business. Therefore, pressure-sensitive institutional directors may behave in the interests of those whom they represent, and not in the interests of the company's stakeholders. As a result, they will be less likely to require the 
disclosure of CSR information. This suggests a negative association between pressuresensitive institutional directors and CSR disclosure, consistent with the collusion hypothesis, which argues that some directors may have incentives to collude with managers. This negative association would mean that pressure-sensitive institutional directors would not press managers to be involved with CSR reporting.

On the other hand, pressure-resistant directors, who represent institutional investors with no business links but only investment ties to the firm and may be mutual funds, investment funds, pension funds or venture capital firms, play a monitoring and disciplinary role on boards (López-Iturriaga et al., 2015). In contrast to pressure-sensitive institutional directors, pressure-resistant directors do not face a conflict of interests, as those they represent do not maintain any business relationship with the firm. Accordingly, these directors are able to discipline managers. Furthermore, Finkelstein (1992) argues that public pension funds and mutual funds, among others, have no "fear of retribution" from the firm's managers because they can be involved in corporate governance matters without being influenced by them.

Pressure-resistant institutional directors will prefer sustainable firms because the costs associated with monitoring the managers of such firms are lower. Furthermore, Johnson and Greening (1999) find that pressure-resistant institutional directors have a positive effect on CSR issues. More concretely, these authors provide evidence that pension funds have a positive impact on product quality (which includes the environment), the community, human talent matters, gender diversity and minorities. Given that the benefits related to CSR disclosure are derived in the long term, and pressure-resistant directors on boards are characterized by a long-term horizon, the integration between these directors and CSR disclosure is relevant. This argument is also supported by Sethi (2005), who shows that pension funds perform a very relevant role in corporate governance, as they try to ensure that firms have a long-term perspective, which may encourage more CSR firms' disclosure. 
Furthermore, Cotter and Najah (2012) provide evidence that large institutional investors, such as pension funds, press firms on climate change issues. According to this evidence, the pressure exerted by their stakeholders means that firms must be concerned about CSR matters if they are to be competitive. Consequently, we expect that pressure-resistant institutional directors will have a positive impact on CSR disclosure, in line with the supervision (contest or monitoring) hypothesis, which argues that some directors have the motivation to supervise the management team. Such directors will be concerned for their reputation and, accordingly, will persuade the management to report on CSR issues.

Consequently, we posit the following two hypotheses:

$\mathrm{H}_{2}$ : CSR disclosure is negatively affected by pressure-sensitive institutional directors.

$\mathrm{H}_{3}$ : CSR disclosure is positively affected by pressure-resistant institutional directors.

\section{EMPIRICAL DESIGN}

\subsection{Sample}

Our sample consists of listed Spanish non-financial firms from 2004 to 2013. Financial entities have been excluded from the sample for several reasons: (1) because they are under special scrutiny by financial authorities that constrain the role of their board of directors and (2) due to the special accounting principles and rules that they have to comply with when preparing their financial statements, which make it more difficult to compare them with those of non-financial firms since they are not homogenous. Our final sample, after excluding financial entities, is composed of an unbalanced panel dataset of 1,018 firm-year observations. Our panel is unbalanced because during the period of the study some companies were acquired or merged and, consequently, were de-listed, while other companies went bankrupt or became public companies. According to Arellano (2003), the findings provided by an unbalanced panel are as reliable as those reported for a balanced panel and, therefore, there is no concern regarding bias derived from missing data. 
The information used to construct the CSR index was collected from web pages of firms (annual sustainability reports) and the Global Reporting Initiative (GRI) website, on which the annual GRI report of companies that have voluntarily disclosed CSR information can be found. Financial data (total assets, total debts and earnings before interest and taxation for measuring the variables leverage, return on assets and firm size) were collected from the financial statements, and corporate governance data (the proportion of institutional, pressuresensitive and pressure-resistant directors, the proportion of stocks owned by insiders, board independence and board size) were obtained from the annual corporate governance reports. Sector data were also collected from the financial reports. Both financial and corporate governance reports must be annually disclosed by listed firms in the Public Register of the Spanish Securities Market Commission (CNMV).

\subsection{Variables}

Our dependent variable, CSR disclosure or reporting, is defined as the CSR_Index and is created using social, environmental and stakeholder information, since CSR is a multidimensional concept (Peloza and Shang, 2011). We base our CSR_Index on CuadradoBallestero et al. (2015), who focus on the three types of information mentioned above to construct their CSR disclosure measure, which is also consistent with the recent papers of Jaggi et al. (2017) and Liu and Zhang (2017), who analyze the voluntary disclosure of carbon information among Italian firms and of CSR information among Chinese companies, respectively. In line with these papers, we also employ content analysis to capture CSR information.

We examine the three matters mentioned above as follows. First, we consider the social information reported by Spanish listed companies. Thus, we analyze information in sustainability reports regarding social labor performed by firms, using their resources (such as financial or human resources) to alleviate social problems or to help underprivileged social 
groups. In this vein, some companies may, for example, allocate a percentage of their profits to social activities or allow employees to dedicate part of their time to cooperating with NGOs without reducing their salaries. Secondly, we analyze the environmental information disclosed by the listed firms, taking into account whether they disclose information in their sustainability reports about the impact of their activities on the environment and how they alter their activities if they do affect the environment, their environmental management system and their policies and environmental commitments. Finally, regarding stakeholder information disclosure, we bear in mind the level of commitment undertaken by the firm. In relation to this, we explore issues such as management systems for general interest groups, gender diversity, development of employees, human rights matters and relationships with customers and suppliers. To the best of our knowledge, no prior research conducted with Spanish listed firms has, in contrast to our analysis, considered all economic sectors in order to construct the CSR disclosure measure.

For each area (social, environmental and stakeholder information), a company is awarded one point if it gives complete information (meaning that the company reports information on every item we have considered for that particular area). If a company does not disclose any information about the areas we take into account, it receives zero points. A company receives half a point if it partially discloses information. For instance, if in the environmental area we take into account four items and the firm discloses information about one, two or three of them, this is considered partial disclosure.

Thus, the CSR_Index is calculated as follows:

\section{CSR_Index}

$=\frac{\sum(\text { score social area }+ \text { score environmental area }+ \text { score stakeholders area })}{3}$

As can be seen, we divide the total score for the firm by 3, which is the maximum score that a firm can attain. 
Then, using the CSR_Index, we classify the firms in the following way: if a firm has a CSR_Index of 0, the firm's CSR disclosure is null; a CSR_Index between 0.1 and 0.5 means that the firm's CSR disclosure is moderate; a CSR_Index between 0.6 and 0.9 represents an acceptable level for the firm's CSR disclosure; and a CSR_Index equal to 1 indicates that the firm's CSR disclosure is complete in respect of the issues we take into account.

Some authors, such as Kim and Lyon (2011), Lyon and Maxwell (2011) and Marquis et al. (2016), base their investigations on selective environmental disclosure or, in other words, on how companies can create a false good image by divulging their positive actions, while hiding their negative impacts on the environment. Toffel (2005) explores why firms voluntarily report regulatory environmental violations, while Reid and Toffel (2009) examine how companies behave under shareholder activism that respects the disclosure of corporate social actions, specifically considering the disclosure of information focused on climate change strategies. Kayser et al. (2014) analyze whether firms voluntarily join environmental and social programs with lax access conditions. More precisely, they analyze whether stakeholder scrutiny encourages companies to participate in the Global Compact program when their prior practices are consistent with the program's principles. In comparison to these papers based on environmental issues, our measure is more complete since it not only takes into account the disclosure of environmental information, but also considers social and stakeholder information reported by the firms. In this way, our index provides a new insight into all the information disclosed by Spanish listed firms on CSR matters.

Several independent variables are used. The variable for the percentage of institutional directors, defined as INST, is calculated as the number of institutional directors on the board of directors as a percentage of the total number of board members. We also consider the representatives of pressure-sensitive and pressure-resistant institutional investors, i.e. pressure-sensitive and pressure-resistant directors, respectively. We label the pressure- 
sensitive directors as SENSIT, and pressure-resistant directors as RESIST, and these variables are calculated as the total number of pressure-sensitive directors on the board as a percentage of the total number of board members, and the total number of pressure-resistant directors on the board as a percentage of the total number of board members, respectively.

Regarding control variables, we consider several factors that may affect the CSR_Index. First, we control for board independence (BINDEP), which is the total number of independent directors on the board as a percentage of the total number of board members. Hence, we expect a positive sign between BINDEP and CSR reporting. Second, leverage (LEV) is measured as the ratio of the book value of debt to the total assets. We predict a positive sign for this variable. Third, we control for profitability or performance, defined as the return on assets (ROA), and calculate this as the ratio of earnings before interest and taxation (EBIT) to book assets. We expect a positive sign for ROA. Fourth, we control for firm size, labeled as SIZE, and measure as the log of the total assets (expressed in thousands of Euros). Consistent with Aragon-Correa et al. (2013), we predict a positive association between SIZE and CSR reporting. Fifth, we consider board size (BSIZE), measured as the total number of board members. De Villiers et al. (2011) show a positive relationship between board size and CSR disclosure. Another control variable considered is insider ownership (INSOWN), calculated as the proportion of stocks held by inside directors. In line with Harjoto and Jo (2011), we predict a negative association between insider ownership and CSR disclosure. We control for the sector, calculated as a dummy variable that takes the value 1 if the firm belongs to the particular sector analyzed and 0, otherwise. Here, we draw on the CNMV classification, which considers the following sectors (labels given in parentheses): transport (TR) (the reference category); cement, glass and construction materials (CGCM); commerce and other services (COMER); construction (CONST); energy and water (EW); financial and insurance (FININS); chemical industry (CHIN); real estate (RE); mass media 
(MASSM); basic metal industries (BMI); other processing industries (OPI); metal processing industries (MPI) and, finally, the remaining sectors not included in any of the above categories and that consist of few firms (OTHR). According to García-Ayuso and Larrinaga (2003), some sectors are more likely to report CSR information than others, as their activities have a greater impact on society. Finally, we also control for firm and year fixed effects.

\section{RESULTS}

\subsection{Descriptive statistics}

Table 1 reports the descriptive statistics for all the variables. The data show that the CSR_Index is, on average, 0.382 out of 1 and, therefore, that the firms in our sample are moderate disclosers of CSR information. Furthermore, the statistics show that, on average, $32.38 \%$ of the directors on a board are institutional, with pressure-sensitive and pressureresistant institutional directors accounting for $6.23 \%$ and $26.15 \%$, respectively. In addition, $31.91 \%$ of the directors are independent directors, on average, and the mean for insider ownership is $8.72 \%$. Furthermore, the average firm size (the log of the total assets in thousands of Euros) is 13.25 , the average leverage is $52.34 \%$, the average board size is 10.77 members and the average ROA is $3.55 \%$. Finally, the transport sector accounts for $3.34 \%$ of firms, cement, glass and construction materials $2.94 \%$, commerce and other services $10.61 \%$, construction $7.95 \%$, energy and water $7.76 \%$, the financial and insurance sector $2.85 \%$, the chemical industry $3.14 \%$, real estate $11.59 \%$, mass media $3.73 \%$, basic metal industries $4.32 \%$, other processing industries $2.41 \%$, metal processing industries $9.82 \%$ and other sectors $7.76 \%$.

[Insert Table 1 about here]

\subsection{Multivariate analysis}

The correlation matrix has been calculated to test for multicollinearity. The findings, unreported for the sake of brevity, show that all the coefficients are lower than 0.7 , except for 
the pairs INST and RESIST, but this is not a problem because these variables do not interact together in any model. However, Hair et al. (2006:227) suggest that the correlation matrix is not sufficient to check the lack of high correlation values among variables to evaluate the presence of multicollinearity. Accordingly, as Hair et al. (2006) indicate, we have also calculated the variance inflation factor (VIF) and the tolerance (1/VIF), provided in Table 2, where the regression findings are presented. According to Haan (2002), VIFs higher than 10 show multicollinearity concerns. In this study, the highest VIF is 7.21 and, therefore multicollinearity is not a problem.

For estimating the models, we use a Tobit regression because this is designed to estimate linear relationships between variables when there is either left- or right-censoring in the dependent variable. In this paper, the dependent variable, CSR_Index, is either 0 or a positive number and ranges from 0 to 1 . Thus, given that the variable is censored on two sides [0-1], a Tobit regression is most suitable for handling the data. All the assumptions for a Tobit regression are fulfilled. According to Wooldridge (2010), the Tobit model with panel data can be estimated as a pooled or a random effects regression. The likelihood-ratio test of rho $=0$ allows us to discriminate between pooled or random effects (Flanagan, 2004). Our findings of the likelihood-ratio test show that a random effects estimator is more appropriate than a pooled one. Furthermore, we have performed the likelihood-ratio test for heteroskedasticity and the Wooldridge test for autocorrelation in panel data models. While the likelihood-ratio test shows that heteroskedasticity is not a concern in our model, the Wooldridge test finds that autocorrelation is. Thus, autocorrelation problems have been corrected by using the bootstrap standard errors method, which clusters residual standard errors (e.g., Gaynor et al., 2006).

Table 2 shows the results for Model 1, in which the effect of institutional directors on the CSR_Index is analyzed. As expected, the proportion of institutional directors exhibits a 
positive sign, and this is statistically significant. Thus, the first hypothesis cannot be rejected. Our results suggest that institutional directors on boards have a positive impact on CSR disclosure; this is consistent with the findings of authors such as Cox et al. (2004), Neubaum and Zahra (2006) and Zattoni (2011), who find a positive relationship between institutional directors and CSR matters. In this vein, our findings reinforce the argument that institutional directors have a long-term horizon, play an effective monitoring role in relation to managers and are concerned about their reputation; for these reasons, they press managers to disclose CSR information. This evidence supports the supervision hypothesis, because institutional directors will prefer companies that are more involved with CSR disclosure in order to monitor the managers more efficiently. Therefore, firms with more institutional directors on their boards are more likely to report CSR information.

[Insert Table 2 about here]

Table 2 also reports the findings for Models 2 and 3, in which we analyze how pressure-sensitive institutional directors and pressure-resistant institutional directors, respectively, affect CSR reporting.

Model 2 in Table 2 shows that the percentage of pressure-sensitive institutional directors, as predicted, shows a negative sign; however, this result is insignificant. Thus, we reject the second hypothesis. Consequently, this finding suggests that pressure-sensitive institutional directors do not have an impact on CSR reporting, and this result is in line with the findings of Johnson and Greening (1999), who found that pressure-sensitive institutional directors did not have an effect on CSR disclosure. However, our results, contrary to our expectations, do not support the collusion hypothesis for this type of director. According to Johnson and Greening (1999), the fact that these directors frequently change their portfolios, and that the long-term profits derived from firms' CSR activities are not of interest to them, may explain the lack of impact of pressure-sensitive institutional directors on CSR disclosure. 
Model 3 in Table 2 reports that the proportion of pressure-resistant institutional directors exhibits a positive sign, as predicted. Moreover, this result is statistically significant. Hence, the third hypothesis cannot be rejected. Accordingly, our findings suggest that pressure-resistant institutional directors have a positive effect on CSR disclosure, which is in line with the findings of Johnson and Greening (1999) suggesting that pressure-resistant institutional directors are more likely to encourage the disclosure of social, stakeholder and environmental information. This evidence supports the idea that pressure-resistant institutional directors prefer firms that are more committed to CSR reporting because the costs associated with monitoring managers in such firms are lower. In addition, pressureresistant directors are concerned with their reputation, have a long-term perspective and prefer firms that are more involved with CSR matters. This result supports the thesis that pressureresistant institutional directors have incentives to encourage managers to disclose information about CSR activities, which is consistent with the results of Sethi (2005) and with the monitoring hypothesis.

Concerning the control variables, board independence (BINDEP) and firm size (SIZE) are positive and statistically associated with CSR disclosure in all models displayed in Table 2. The control variable insider ownership (INSOWN) shows a negative sign, according to our expectations, and this is statistically significant in all models. Finally, our findings demonstrate which sectors disclose more or less CSR information compared to the transport sector (TR - the reference category). In particular, compared to TR, the construction (CONST) and basic metal industries (BMI) sectors show a positive sign on CSR disclosure, and the results are statistically significant. The commerce and other services (COMER), the energy and water (EW), the mass media (MASSM) and other processing industries (OPI) sectors also present a positive sign in comparison to the transport sector, but the findings show that the COMER, MASSM and OPI sectors are only statistically significant in Models 1 
and 3 and for the EW sector in Model 1. Therefore, the aforementioned sectors positively affect CSR reporting, which is a logical consequence of the high environmental and social impact of their activities. Thus, compared to the transport sector, all these sectors disclose more CSR information. By contrast, compared to TR, the real estate (RE) sector is negatively associated with CSR reporting in a statistically significant way, which implies that the real sector reports less CSR information than the transport sector. The remaining variables are insignificant.

We also address the issue of possible endogeneity between our independent variables (INST, SENSIT and RESIST) and CSR disclosure. The direction of causality between the independent variables and CSR reporting is more likely to go from the directors analyzed in the paper to CSR disclosure, although it is also likely that CSR disclosure has an effect on board composition. This matter is addressed by lagging the independent variables in our models. For the sake of brevity, these findings are not shown, but they are in line with the core results of our analysis.

\subsection{Sensitivity analysis}

We check the robustness of our models using, as the dependent variable, the ratio between the CSR_Index and the firm size (SIZE), since firm size is a factor that has a positive effect on CSR reporting, as our results show: bigger companies are more likely to disclose CSR information than smaller ones. The results, which for the sake of brevity are not provided, demonstrate that the proportions of institutional directors (INST) and pressureresistant institutional directors (RESIST) exhibit a positive sign, as expected, and are statistically significant. Regarding pressure-sensitive institutional directors (SENSIT), the results are insignificant. Hence, this evidence corroborates our results and, accordingly, we can affirm that our findings do not depend on the measure of CSR reporting. 


\section{DISCUSSION AND CONCLUSIONS}

Our paper tries to fill the gap in the literature concerning the role played by institutional directors in firms' decision-making processes in relation to CSR disclosure. To deepen the analysis of institutional directors and their impact on CSR disclosure, we also distinguish between institutional directors who represent institutional investors with business ties to the company and institutional directors who represent institutional investors that do not maintain such business links.

Our results reveal that institutional and pressure-resistant directors have a positive effect on CSR disclosure. This finding supports the monitoring hypothesis, stressing the importance of reputation for these directors, in line with their long-term perspective. Their preferences for long-term investments and for mitigating agency costs support the view that institutional and pressure-resistant directors may have sufficient power to supervise managers and activities, to reduce opportunistic behavior, to influence company decisions in favor of stakeholders' interests, and to foster changes in companies such as the widening of CSR reporting to include not only economic matters, but also social and environmental ones. In this vein, it will be more complicated for managers to collude with institutional and pressureresistant directors than with other directors since these institutional directors might be interested in sharing supervision costs, resulting in a more active and efficient supervisory role. Furthermore, institutional and pressure-resistant directors on boards may avoid the temptation to join other institutional and pressure-sensitive directors in taking part in tunneling activities (that is, expropriating wealth from minority owners), since managers might influence them to gain their support and, in return, these directors might meet their aims. The more active supervision of managers' activities by these directors might prevent tunneling activities and might challenge the boards of directors and managers to disclose CSR issues. This is because institutional and pressure-resistant directors may link the competitive 
advantages with the benefits provided by CSR; this will lead to the long-term sustainability of the company and an improvement in company performance. Provided that pressure-resistant directors represent institutional investors who do not maintain commercial ties with the firms, they do not face any conflicts of interest arising from such business relationships and, consequently, they can behave in a more independent way. The firms in which the investors have invested can exert less pressure on such directors.

Contrary to our expectations, pressure-sensitive institutional directors do not have an impact on CSR disclosure, suggesting that banks and insurance companies hold short-term positions and, thus, simply seek to enhance their own profit. This result may be explained by arguing that supervision costs are high and that pressure-sensitive directors would have to bear these costs if they engaged in supervision, while sharing the benefits of the supervision with all the other stakeholders. This will discourage pressure-sensitive directors from becoming involved with monitoring any activities that could increase the CSR reporting. Moreover, pressure-sensitive directors might influence the decision-making process for their own benefit, and in order to achieve their own aims they might prefer to align themselves with the company. Thus, it is reasonable to suggest that pressure-sensitive directors may be interested in taking part in tunneling activities rather than supervision activities. Consequently, pressure-sensitive directors might not be interested in promoting CSR reporting, even though CSR disclosure may increase firm value. Following this line of argument, pressure-sensitive directors will be more interested in obtaining private benefits for the investors they represent than in enhancing firm performance, and more interested in monitoring other pressure-sensitive directors in order to prevent them from achieving their own purposes. Pressure-sensitive directors will align themselves with managers and will be less willing to confront them with CSR reporting; this is a result of the conflicts of interest faced by pressure-sensitive institutional directors because of the business ties between the 
firm and the pressure-sensitive institutional investors they represent. If these directors do not align themselves with managers, they might compromise these commercial links. Hence, pressure-sensitive directors may collude with managers, aligning themselves with their views and decisions, such as decisions not to disclose CSR information, and in this way, pressuresensitive directors may meet their own aims and preserve the commercial relationships. Additionally, pressure-sensitive directors tend to be interested in short-term earnings and, consequently, may support activities that increase short-term profitability; CSR reporting is not one of these activities because its benefits are displayed across a long-term horizon. Thus, the supervision costs, the conflict of interest felt by pressure-sensitive directors and these directors' short-term orientation support the absence of influence of these directors on CSR disclosure.

This research has significant implications. Our results offer a new insight into the positive role played by institutional directors, particularly pressure-resistant directors, on CSR disclosure and may, therefore, help policymakers to promote CSR reporting in the Spanish context, where almost $40 \%$ of board members are institutional directors. Hence, this result has important implications for both public policy and the governance of firms. When there are differences between institutional directors, especially pressure-resistant directors, and other experienced directors, then the interests of the institutional directors would mainly become a public policy matter. Regulatory bodies may recommend board structures with institutional directors, particularly pressure-resistant directors, not only for listed firms, but also for nonlisted firms, since institutional directorship might encourage firms to disclose CSR information, which may be of benefit to all the stakeholders. Non-compliance with these recommendations may be perceived negatively by the capital markets and other funding sources, which may encourage companies to disclose CSR information. Secondly, our results suggest that institutional directors and pressure-resistant directors may challenge boards and 
managers to report on CSR issues, in line with the monitoring hypothesis and, consequently, these directors focus not only on economic performance, but also on environmental and social matters. Accordingly, this evidence supports the view that institutional directors and pressureresistant directors might actively supervise managers and might abandon their conventional inactive role in the supervision of managers, which would have an effect on CSR reporting. Thirdly, our findings offer important evidence in relation to earlier literature by examining whether institutional investors, when they appoint board directors, have an effect on CSR reporting. As a result, when academics examine the role played by institutional investors, they should address not only the number of shares held by institutional investors, but also their contribution to other methods of corporate control such as board membership. Fourthly, our evidence demonstrates that institutional directors should be considered as a heterogeneous group, because pressure-resistant directors have a positive impact on CSR reporting, while pressure-sensitive directors do not have any effect. Fifthly, this paper provides new insights for NGOs, which may consider our evidence when they help companies to get a better understanding of the importance of institutional directors in firms' decisions to disclose CSR information; such disclosures are in the interests of the institutional investors and of society, and they are of special benefit to all stakeholders. Finally, further investigations into the role of institutional directors become essential to give a better understanding of how they engage in efficient corporate governance mechanisms. Although earlier and more recent evidence has shed some light on these matters, academics must go even more deeply into the implications and incentives of institutional directors in the governance of firms.

This research has several limitations. First, despite taking into account as many factors as possible on the basis of theory and the prior empirical evidence, it is likely that there are unknown factors affecting CSR disclosure that have not been considered. Second, our research is based on Spanish listed firms from 2004 to 2013 and, therefore, our findings 
should not be extended to other periods. Third, although a significant percentage of directors on Spanish boards are institutional directors, within this category there are fewer pressuresensitive directors than pressure-resistant directors. Finally, our CSR_Index, based on the prior literature, is composed of three areas and is measured using many factors, but it is possible that other characteristics having an impact on the three areas of our analysis have not been addressed.

Finally, this investigation leads to suggestions for future research. First, it may be interesting to analyze the role played by institutional directors in relation to CSR disclosure for Spanish financial entities, and for small to medium-sized enterprises (SMEs). Secondly, it would also be interesting to explore whether there are institutional directors appointed by NGOs on the boards of listed and non-listed firms, and the role that these directors perform in relation to CSR reporting, given the work in society undertaken by NGOs. Finally, the number of female directors of listed firms is increasing, particularly in Spain, and consequently, the role played by female institutional directors in relation to CSR disclosure is also a relevant topic.

\section{REFERENCES}

Angelidis, J.P. and Ibrahim, N.A. (1993). Social demand and corporate strategy: a corporate social responsibility model. Review of Business, 15(1), 7-10.

Ali, A., Chen, T. Y. and Radhakrishnan, S. (2007). Corporate disclosures by family firms. Journal of Accounting and Economics, 44(1), 238-286.

Almazan, A., Hartzell, J. C. and Starks, L. T. (2005). Active institutional shareholders and costs of monitoring: Evidence from executive compensation. Financial Management, 34(4), $5-34$.

Aragon-Correa, J.A., Martin-Tapia, I. and Hurtado-Torres, N.E. (2013). Proactive environmental strategies and employee inclusion: The positive effects of information 
sharing and promoting collaboration and the influence of uncertainty. Organization \& Environment, 26(2) 139-161.

Arellano, M. (2003). Panel data econometrics. Oxford: Oxford University Press.

Arjoon, S. (2005). Corporate governance: An ethical perspective. Journal of Business Ethics, 61(4), 343-352.

Bhojraj, S. and Sengupta, P. (2003). Effect of corporate governance on bond ratings and yields: The role of institutional investors and outside directors. The Journal of Business, $76(3), 455-475$.

Bowen, F., and Aragon-Correa J. A. (2014). Greenwashing in corporate environmentalism research and practice. Organization \& Environment, 27(2), 107-112.

Choi, S.B., Park, B.I., Hong, P. (2012). Does ownership structure matter for firm technological innovation performance?. The case of Korean firms. Corporate Governance: An International Review, 20(3), 267-288.

Colpan, A. M. and Yoshikawa, T. (2012). Performance sensitivity of executive pay: the role of foreign investors and affiliated directors in Japan. Corporate Governance: An International Review, 20(6), 547-561.

Connelly, B.L., Certo, S.T., Ireland, R.D. and Reutzel, C.R. (2010). Signaling theory: a review and assessment. Journal of Management, 37, 39-67.

Cotter, J. and Najah, M. M. (2012). Institutional investor influence on global climate change disclosure practices. Australian Journal of Management, 37(2), 169-187.

Cox, P., Brammer, S. and Millington, A. (2004). An empirical examination of institutional investor preferences for corporate social performance. Journal of Business Ethics, 52(1), 27 43.

Crespí, R., García-Cestona, M. A. and Salas, V. (2004). Governance mechanisms in Spanish banks. Does ownership matter?. Journal of Banking \& Finance, 28(10), 2311-2330. 
Cuadrado-Ballestero, B., García-Rubio, R. and Martínez-Ferrero, J. (2015). Efecto de la composición del consejo de administración en las prácticas de responsabilidad social corporativa. Spanish Accounting Review, 18(1), 20-31.

CUBG (2006). Código Unificado de Buen Gobierno de las Sociedades Cotizadas (Conthe Code). Comisión Nacional del Mercado de Valores (CNMV), Madrid. www.cnmv.es

David, P., Hitt, M. A. and Gimeno, J. (2001). The influence of activism by institutional investors on R\&D. Academy of Management Journal, 44(1), 144-157.

David, P., Kochhar, R. and Levitas, E. (1998). The effect of institutional investors on the level and mix of CEO compensation. Academy of Management Journal, 41(2), 200-208.

Davis, G. F. and Thompson, T. A. 1994. A social movement perspective on corporate control. Administrative Science Quarterly, 39, 141-173.

De Villiers, C., Naiker, V. and Van Staden, C. J. (2011). The effect of board characteristics on firm environmental performance. Journal of Management, 37(6), 1636-1663.

Dienes, D., Sassen, R. and Fischer, J. (2016). What are the drivers of sustainability reporting?. A systematic review. Sustainability Accounting, Management and Policy Journal, 7(2), 154189.

Eesley, C., DeCelles, K. A. and Lenox, M. (2016). Through the mud or in the boardroom: Examining activist types and their strategies in targeting firms for social change. Strategic Management Journal, 37(12), 2425-2440.

Eng, L. L. (1999). Comparing changes in stockholdings of different institutional investors. The Journal of Investing, 8(1), 46-50.

European Commission. (2001). Green Paper: Promoting a European framework for corporate social responsibility. Office for Official Publications of the European Communities. Brussels, Belgium. 
European Commission. (2005). Modernising Company Law and Enhancing Corporate Governance in the European Union - A Plan to Move Forward. Brussels, Belgium.

Fernandez-Feijoo, B., Romero, S. and Ruiz-Blanco, S. (2014). Women on boards: do they affect sustainability reporting?. Corporate Social Responsibility and Environmental Management, 21(6), 351-364.

Fernández-Sánchez, J.L., Luna-Sotorrío, L. and Baraibar-Díez, E. (2011). The relationship between corporate governance and corporate social behaviour: A structural equation model analysis. Corporate Social Responsibility and Environmental Management, 18(2), 91-101.

Ferrarini, G. and Filippelli, M. (2013). Independent directors and controlling shareholders. Orizzonti del Diritto Commerciale, 2, 1-31.

Finkelstein, S. (1992). Power in top management teams: Dimensions, measurement, and validation. Academy of Management Journal, 35(3), 505-538.

Flanagan, J.O. (2014). Spatial prioritisation of conservation areas on the fringes of KwaZuluNatal protected areas: application of the characteristics framework using tourism competitiveness. Thesis of the degree of Master of Science in Agriculture (Agribusiness). University of KwaZulu-Natal, Pietermaritzburg, South Africa.

Font, X., Walmsley, A., Cogotti, S., McCombes, L. and Häusler, N. (2012). Corporate social responsibility: The disclosure-performance gap. Tourism Management, 33(6), 1544-1553.

Freeman, R. E. (2010). Strategic management: A stakeholder approach. Cambridge University Press, Cambridge, UK.

Frias-Aceituno, J.V., Rodríguez-Ariza, L. and García-Sánchez, I.M. (2013). The role of the board in the dissemination of integrated corporate social reporting. Corporate Social Responsibility and Environmental Management, 20(4), 219-233.

Galbreath, J. (2016). The Impact of Board Structure on Corporate Social Responsibility: A Temporal View. Business Strategy and the Environment. Forthcoming. 
García-Ayuso, M. and Larrinaga, C. (2003). Environmental disclosure in Spain: Corporate characteristics and media exposure. Spanish Journal of Finance and Accounting/Revista Española de Financiación y Contabilidad, 32(115), 184-214.

García-Meca, E. and Sánchez-Ballesta, J.P. and (2009). Corporate Governance and earnings management: a meta-analysis. Corporate Governance: An International Review, 17(5), 594610.

Gaynor, M., Li, J. And Vogt, W.B. (2006). Is drug coverage a free lunch?. Cross-price elasticities and the design of prescription drug benefits. NBER Working paper series. Machachusetts, USA.

Haan, C.T. (2002). Statistical Methods in Hydrology. Las Vegas, Nevada: Iowa State University Press.

Hahn, R. and Kuhnen, M. (2013). Determinants of sustainability reporting: a review of results, trends, theory, and opportunities in an expanding field of research. Journal of Cleaner Production, 59, 5-21.

Hair, J. F., Black, W. C., Babin, B. J., Anderson, R. E. and Tatham, R. L. (2006). Multivariate Data Analysis. Sixth Edition, Pearson Prentice Hall, New Jersey, USA.

Harjoto, M. A. and Jo, H. (2011). Corporate governance and CSR nexus. Journal of Business Ethics, 100(1), 45-67.

Hartzell, J. and Starks, L. T. (2003). Institutional investors and executive compensation, Journal of Finance, 58, 2351-74.

Heidrick and Struggles (2011). European Corporate Governance Report 2011: Challenging Board Performance.

Huse, M. (2007). Boards, governance and value creation: The human side of corporate governance. Cambridge University Press. 
Jaggi, B., Allini, A., Macchioni, R. and Zagaria, C. (2017). The factors motivating voluntary disclsoure of carbon information: Evidence based on Italian listed companies. Organization \& Environment, DOI: https://doi.org/10.1177/1086026617705282

Jain, T. and Jamali, D. (2016). Looking inside the black box: the effect of corporate governance on corporate social responsibility. Corporate Governance: An International Review, 24(3), 253-273.

Jizi, M., Salama, A., Dixon, R. and Stratling, R. (2014). Corporate governance and corporate social responsibility disclosure: evidence from the US banking sector. Journal of Business Ethics, 125(4), 601-615.

Johnson, R. A. and Greening, D. W. (1999). The effects of corporate governance and institutional ownership types on corporate social performance. Academy of Management Journal, 42(5), 564-576.

Kayser, S. A., Toffel, M. W. and Maxwell, J. W. (2014). Is there a cost to joining a 'free'voluntary program? The role of stakeholder scrutiny. In Sixth Annual ARCS Research Conference, New York.

Kent, P. and Monem, R. (2008). What drives TBL reporting: good governance or threat to legitimacy?. Australian Accounting Review, 18(4), 297-309.

Kim, E.H. and Lyon, T.P. (2011). Strategic environmental disclosure: Evidence from the DOE's Voluntary Greenhouse Gas Registry. Journal of Environmental Economics and Management, 61(3), 311-326.

Liu, X. and Zhang, C. (2017). Corporate governance, social responsibility information disclosure, and enterprise value in China. Journal of Cleaner Production, 142, 1075-1084.

López-Iturriaga, F. J., García-Meca, E. and Tejerina Gaite, F. (2015). Institutional directors and board compensation: Spanish evidence. BRQ Business Research Quarterly, 18(3), 161173. 
Lyon, T.P. and Maxwell, J.W. (2011). Greenwash: Environmental disclosure under threat of audit. Journal of Economics and Management Strategy, 20(1), 3-41.

Mahapatra S. (1984). Investor reaction to corporate social accounting. Journal of Business Financial and Accounting, 11, 29-40.

Marquis, C., Toffel, M. W. and Zhou, Y. (2016). Scrutiny, norms, and selective disclosure: A global study of Greenwashing. Organizational Science, 27(2), 483-504.

Miras-Rodríguez, M., Carrasco-Gallego, A. and Escobar-Pérez, B. (2015). Are socially responsible behaviours paid off equally? A cross-cultural analysis. Corporate Social Responsibility and Environmental Management, 22(4), 237-256.

Montiel, I. and Delgado-Ceballos, J. (2014). Defining and measuring corporate sustainability are we there yet?. Organization \& Environment, 27(2), 113-139.

Morsing, M. and Schultz, M. (2006). Corporate social responsibility communication: stakeholder information, response and involvement strategies. Business Ethics: A European Review, 15(4), 323-338.

Neubaum, D. O. and Zahra, S. A. (2006). Institutional ownership and corporate social performance: The moderating effects of investment horizon, activism, and coordination. Journal of Management, 32(1), 108-131.

Olcese, A. (2012). Informe sobre la Responsabilidad Social de la Empresa en España. Una propuesta para Europa. Comisión Europea. Bruselas.

Panwar, R., Paul, K., Nybakk, E., Hansen, E. and Thompson, D. (2014). The legitimacy of CSR actions of publicly traded companies versus family-owned companies. Journal of Business Ethics, 125(3), 481-496.

Parrino, R., Sias, R. W. and Starks, L. T. (2003). Voting with their feet: Institutional ownership changes around forced CEO turnover. Journal of Financial Economics, 68, 3-46. 
Patten, D.M. and Crampton, W. (2004). Legitimacy and the internet: An examination of corporate web page environmental disclosures. Advances in Environmental Accounting and Management, 2, 31-58.

Peloza, J., and Shang, J. (2011). How can corporate social responsibility activities create value for stakeholders? A systematic review. Journal of the Academy of Marketing Science, 39(1), $117-135$

Pucheta-Martínez, M. C. and García-Meca, E. (2014). Institutional investors on boards and audit committees and their effects on financial reporting quality. Corporate Governance: An International Review, 22(4), 347-363.

Ramalingegowda, S. and Yu, Y. (2012). Institutional ownership and conservatism. Journal of Accounting and Economics, 53(1), 98-114.

Ramchander, S., Schwebach, R. G. and Staking, K. (2012). The informational relevance of corporate social responsibility: Evidence from DS400 index reconstitutions. Strategic Management Journal, 33, 303-314.

Reid, E. M. and Toffel, M. W. (2009). Responding to public and private politics: Corporate disclosure of climate change strategies. Strategic Management Journal, 30 (11), 1157-1178.

Sánchez-Ballesta, J. P. and García-Meca, E. (2007). A meta-analytic vision of the effect of ownership structure on firm performance. Corporate Governance: An International Review, 15(5), 879-892.

Santos, C. M. (2011). La responsabilidad social corporativa como criterio de gestión empresarial. Lan Harremanak. Revista de Relaciones Laborales, 14, 43-55

Sethi, S. P. (2005). Investing in socially responsible companies is a must for public pension funds-because there is no better alternative. Journal of Business Ethics, 56(2), 99-129.

Toffel, M. W. (2005). Voluntary environmental management initiatives: smoke signals or smoke screens?. Doctoral dissertation, University of California, Berkeley. 
Waddock, S. (2003). Stakeholder performance implications of corporate responsibility. International Journal of Business Performance Management, 5(2), 114-124.

Walls, J. L., Berrone, P. and Phan, P. H. (2012). Corporate governance and environmental performance: is there really a link?. Strategic Management Journal, 33(8), 885-913.

Walls, J. L. and Hoffman, A. J. (2013). Exceptional boards: Environmental experience and positive deviance from institutional norms. Journal of Organizational Behavior, 34(2), 253271.

Wooldridge, J.M. (2010). Econometric Analysis of Cross Section and Panel Data. The MIT Press, Cambridge, Massachusetts.

Zattoni, A. (2011). Who should control a corporation? Toward a contingency stakeholder model for allocating ownership rights. Journal of Business Ethics, 103(2), 255-274. 
Table 1

Main Descriptive Statistics

\begin{tabular}{|c|c|c|c|c|c|c|}
\hline \multicolumn{7}{|c|}{ Panel A. Continuous variables } \\
\hline Variables & $\mathbf{N}$ & Mean & Std. Dev. & Perc. $25^{\text {th }}$ & Perc. 50 ${ }^{\text {th }}$ & Perc. $75^{\text {th }}$ \\
\hline CSR_Index & 1.018 & 0.382 & 0.439 & 0.000 & 0.000 & 0.833 \\
\hline INST & 1.018 & 32.384 & 23.922 & 14.000 & 29.500 & 50.000 \\
\hline SENSIT & 1.018 & 6.233 & 11.359 & 0.000 & 0.000 & 10.000 \\
\hline RESIST & 1.018 & 26.151 & 23.983 & 0.000 & 20.000 & 44.000 \\
\hline BINDEP & 1.018 & 31.913 & 17.984 & 21.000 & 30.884 & 42.857 \\
\hline LEV & 1.018 & 52.344 & 23.583 & 34.352 & 54.852 & 70.150 \\
\hline ROA & 1.018 & 3.550 & 14.820 & -0.834 & 3.227 & 8.343 \\
\hline SIZE & 1.018 & 13.249 & 1.803 & 11.897 & 13.089 & 14.476 \\
\hline BSIZE & 1.018 & 10.767 & 3.801 & 8.000 & 10.000 & 13.000 \\
\hline INSOWN & 1.018 & 8.719 & 17.274 & 0.000 & 0.103 & 8.452 \\
\hline \multicolumn{7}{|c|}{ Panel B. Dummies variables } \\
\hline & \multicolumn{4}{|c|}{$\begin{array}{l}\% \text { of firms of the sample } \\
\text { that do not operate in the } \\
\text { sector analysed }\end{array}$} & \multicolumn{2}{|c|}{$\begin{array}{l}\% \text { of firms of the } \\
\text { sample that operate in } \\
\text { the sector analysed }\end{array}$} \\
\hline $\mathrm{TR}$ & & \multicolumn{3}{|c|}{$96.66 \%$} & \multicolumn{2}{|r|}{$3.34 \%$} \\
\hline CGCM & & \multicolumn{3}{|c|}{$97.05 \%$} & \multicolumn{2}{|r|}{$2.94 \%$} \\
\hline COMER & & \multicolumn{3}{|c|}{$89.39 \%$} & \multicolumn{2}{|r|}{$10.61 \%$} \\
\hline CONST & & \multicolumn{3}{|c|}{$92.04 \%$} & \multicolumn{2}{|r|}{$7.95 \%$} \\
\hline EW & & \multicolumn{3}{|c|}{$92.24 \%$} & \multicolumn{2}{|r|}{$7.76 \%$} \\
\hline FININS & & \multicolumn{3}{|c|}{$97.15 \%$} & \multicolumn{2}{|r|}{$2.85 \%$} \\
\hline CHIN & & \multicolumn{3}{|c|}{$96.86 \%$} & \multicolumn{2}{|r|}{$3.14 \%$} \\
\hline $\mathrm{RE}$ & & \multicolumn{3}{|c|}{$88.41 \%$} & \multicolumn{2}{|r|}{$11.59 \%$} \\
\hline MASSM & & \multicolumn{3}{|c|}{$96.27 \%$} & \multicolumn{2}{|r|}{$3.73 \%$} \\
\hline BMI & & \multicolumn{3}{|c|}{$95.68 \%$} & \multicolumn{2}{|r|}{$4.32 \%$} \\
\hline OPI & & \multicolumn{3}{|c|}{$97.59 \%$} & \multicolumn{2}{|r|}{$24,06 \%$} \\
\hline MPI & & \multicolumn{3}{|c|}{$90.18 \%$} & \multicolumn{2}{|r|}{$9.82 \%$} \\
\hline OTHR & & \multicolumn{3}{|c|}{$92.24 \%$} & \multicolumn{2}{|r|}{$7.76 \%$} \\
\hline
\end{tabular}

Mean, standard deviation and percentiles $25^{\text {th }}, 50^{\text {th }}$ and $75^{\text {th }}$. Panel A and B show the continuous and dummy variables, respectively. CSR_Index is the dependent variable, measured as the sum of the score of the three areas analyzed divided by 3 ; INST is the proportion of institutional directors on board; SENSIT is the proportion of the board directors who are representative of pressure-sensitive institutional investors (i.e., banks and insurance companies); RESIST is the proportion of the board directors who are representative of pressure-resistant institutional investors (i.e., investment funds); INDEP is the proportion of independent directors on the board; BDSIZE is the number of directors on boards; LEV is the debt over total assets; ROA is the operate income before interests and taxes over total assets; SIZE is the log of total assets; BSIZE is the number of member on boards; INSOWN is the percentage of shares held by insiders (directors) on board and from TR to OTHR represent the sectors of the firms, measured as dummy variables that take the value 1 if the company belongs to the sector analyzed and 0 , otherwise. 
Table 2

Results of the Tobit regression for institutional, pressure-sensitive and pressure-resistant directors sit on boards

\begin{tabular}{|c|c|c|c|c|c|c|c|c|c|c|}
\hline Variables & $\begin{array}{l}\text { Expected } \\
\text { Sign }\end{array}$ & $\begin{array}{c}\text { Model } 1 \\
\text { Estimated coefficient } \\
\text { (p.value) }\end{array}$ & VIF & Tolerance & $\begin{array}{c}\text { Model } 2 \\
\text { Estimated coefficient } \\
\text { (p.value) }\end{array}$ & VIF & Tolerance & $\begin{array}{c}\text { Model } 3 \\
\text { Estimated coefficient } \\
\text { (p.value) }\end{array}$ & VIF & Tolerance \\
\hline INST & + & $\begin{array}{l}0.004 * \\
(0.096)\end{array}$ & 1.48 & 0.676 & & & & & & \\
\hline SENSIT & - & & & & $\begin{array}{l}-0.006 \\
(0.388)\end{array}$ & 1.25 & 0.799 & & & \\
\hline RESIST & + & & & & & & & $\begin{array}{l}0.006^{*} \\
(0.091)\end{array}$ & 1.34 & 0.746 \\
\hline BINDEP & + & $\begin{array}{c}0.017 * * * \\
(0.001)\end{array}$ & 1.47 & 0.678 & $\begin{array}{c}0.013 * * * \\
(0.005)\end{array}$ & 1.27 & 0.785 & $\begin{array}{c}0.017 * * * \\
(0.001)\end{array}$ & 1.39 & 0.719 \\
\hline LEV & + & $\begin{array}{c}0.001 \\
(0.729)\end{array}$ & 1.44 & 0.697 & $\begin{array}{c}0.001 \\
(0.779)\end{array}$ & 1.44 & 0.695 & $\begin{array}{c}0.001 \\
(0.777)\end{array}$ & 1.44 & 0.695 \\
\hline ROA & + & $\begin{array}{c}0.006 \\
(0.215)\end{array}$ & 1.16 & 0.859 & $\begin{array}{c}0.006 \\
(0.194)\end{array}$ & 1.17 & 0.857 & $\begin{array}{c}0.006 \\
(0.198)\end{array}$ & 1.17 & 0.857 \\
\hline SIZE & + & $\begin{array}{c}0.470 * * * \\
(0.000)\end{array}$ & 2.76 & 0.362 & $\begin{array}{c}0.471 * * * \\
(0.000)\end{array}$ & 2.83 & 0.353 & $\begin{array}{c}0.477 * * * \\
(0.000)\end{array}$ & 2.78 & 0.359 \\
\hline BSIZE & + & $\begin{array}{c}0.026 \\
(0.304)\end{array}$ & 1.87 & 0.5349 & $\begin{array}{c}0.038 \\
(0.132)\end{array}$ & 1.88 & 0.533 & $\begin{array}{c}0.028 \\
(0.255)\end{array}$ & 1.84 & 0.544 \\
\hline INSOWN & - & $\begin{array}{l}-0.008^{*} \\
(0.079)\end{array}$ & 1.26 & 0.792 & $\begin{array}{l}-0.009^{*} \\
(0.075)\end{array}$ & 1.20 & 0.831 & $\begin{array}{l}-0.008^{*} \\
(0.082)\end{array}$ & 1.24 & 0.803 \\
\hline CGCM & $+/-$ & $\begin{array}{c}0.508 \\
(0.395)\end{array}$ & 1.87 & 0.535 & $\begin{array}{c}0.332 \\
(0.579)\end{array}$ & 1.93 & 0.517 & $\begin{array}{c}0.413 \\
(0.477)\end{array}$ & 1.88 & 0.532 \\
\hline COMER & $+/-$ & $\begin{array}{l}0.879^{*} \\
(0.061)\end{array}$ & 4.41 & 0.227 & $\begin{array}{c}0.758 \\
(0.127)\end{array}$ & 4.46 & 0.224 & $\begin{array}{l}0.835^{*} \\
(0.078)\end{array}$ & 4.42 & 0.226 \\
\hline CONST & $+/-$ & $\begin{array}{l}0.966^{* *} \\
(0.011)\end{array}$ & 3.13 & 0.319 & $\begin{array}{l}0.788^{*} \\
(0.058)\end{array}$ & 3.32 & 0.301 & $\begin{array}{c}0.864 * * \\
(0.016)\end{array}$ & 3.18 & 0.315 \\
\hline EW & $+/-$ & $\begin{array}{l}0.783^{*} \\
(0.087)\end{array}$ & 3.06 & 0.327 & $\begin{array}{c}0.631 \\
(0.158)\end{array}$ & 3.14 & 0.301 & $\begin{array}{c}0.703 \\
(0.108)\end{array}$ & 3.06 & 0.326 \\
\hline FININS & $+/-$ & $\begin{array}{l}-0.051 \\
(0.947)\end{array}$ & 1.95 & 0.514 & $\begin{array}{l}-0.187 \\
(0.802)\end{array}$ & 1.96 & 0.509 & $\begin{array}{l}-0.140 \\
(0.851)\end{array}$ & 1.96 & 0.509 \\
\hline CHIN & $+/-$ & $\begin{array}{c}0.849 \\
(0.207)\end{array}$ & 2.09 & 0.477 & $\begin{array}{c}0.641 \\
(0.357)\end{array}$ & 2.11 & 0.474 & $\begin{array}{c}0.795 \\
(0.231)\end{array}$ & 2.08 & 0.480 \\
\hline $\mathrm{RE}$ & $+/-$ & $\begin{array}{c}-1.313^{* *} \\
(0.010)\end{array}$ & 4.48 & 0.223 & $\begin{array}{c}-1.360 * * * \\
(0.009)\end{array}$ & 4.53 & 0.220 & $\begin{array}{c}-1.345^{* * *} \\
(0.008)\end{array}$ & 4.53 & 0.220 \\
\hline MASSM & $+/-$ & $\begin{array}{l}1.039 * * \\
(0.028)\end{array}$ & 2.08 & 0.480 & $\begin{array}{c}0.841 \\
(0.104)\end{array}$ & 2.19 & 0.455 & $\begin{array}{l}0.924^{*} \\
(0.051)\end{array}$ & 2.10 & 0.475 \\
\hline BMI & $+/-$ & $\begin{array}{c}0.814^{* *} \\
(0.038)\end{array}$ & 2.37 & 0.421 & $\begin{array}{l}0.712^{*} \\
(0.091)\end{array}$ & 2.40 & 0.416 & $\begin{array}{l}0.736^{*} \\
(0.066)\end{array}$ & 2.39 & 0.419 \\
\hline OPI & $+/-$ & $\begin{array}{l}0.750^{*} \\
(0.068)\end{array}$ & 7.11 & 0.140 & $\begin{array}{c}0.611 \\
(0.147)\end{array}$ & 7.21 & 0.138 & $\begin{array}{l}0.700^{*} \\
(0.081)\end{array}$ & 7.11 & 0.140 \\
\hline MPI & $+/-$ & $\begin{array}{c}0.320 \\
(0.471)\end{array}$ & 3.99 & 0.250 & $\begin{array}{c}0.154 \\
(0.746)\end{array}$ & 4.09 & 0.244 & $\begin{array}{c}0.250 \\
(0.569)\end{array}$ & 4.00 & 0.250 \\
\hline OTHR & $+/-$ & $\begin{array}{c}0.697 \\
(0.117)\end{array}$ & 3.35 & 0.298 & $\begin{array}{c}0.552 \\
(0.226)\end{array}$ & 3.39 & 0.294 & $\begin{array}{c}0.649 \\
(0.140)\end{array}$ & 3.34 & 0.299 \\
\hline Obs & & 1.018 & & & 1.018 & & & 1.018 & & \\
\hline $\mathrm{R}^{2}$ & & $32.95 \%$ & & & $32.87 \%$ & & & $33.12 \%$ & & \\
\hline
\end{tabular}

Significant at $* * *$ for 99 percent confidence level, ** for 95 percent and * for 90 percent. 